\title{
ODRŽAVANJE KANALIZACIJSKOG SUSTAVA UZ PRIMJENU GIS-a
}

\section{Marija Šperac}

Sveučilište Josipa Jurja Strossmayera u Osijeku, Građevinski fakultet Osijek, doc.dr.sc.

\section{Vladimir Moser}

Sveučilište Josipa Jurja Strossmayera u Osijeku, Građevinski fakultet Osijek, mr.sc., dipl.inž.geod.

\section{Tomislav Stvorić}

Sveučilište Josipa Jurja Strossmayera u Osijeku, Građevinski fakultet Osijek, dipl.inž.građ.

Sažetak: Dobro održavanje kanalizacijskog sustava osnovni je preduvjet za racionalno gospodarenje ovom skupom gradskom infrastrukturom, za dobre sanitarne uvjete u urbanoj sredini i dobru zaštitu okoliša. Dobro održavanje kanalizacije jedan je od preduvjeta za održivi razvoj i zdravstveni standard neke urbane sredine, stoga mu se mora pokloniti velika pozornost. Svrha ovoga rada je pokazati prednosti korištenja GIS-a (Geografski informacijski sustavi ili Geoinformacijski sustavi) u održavanju kanalizacijskog sustava.

Ključne riječi: kanalizacijski sustav, održavanje, GIS, zaštita okoliša

\section{MAINTANCE OF THE SEWERAGE SYSTEM USING GIS}

Abstract: Good maintenance of the sewerage system is a prerequisite for the rational management of this set of urban infrastructure, for good sanitary conditions in the urban environment and a good environment. Good maintenance of sewage is one of the prerequisites for sustainable development and the standard of health of some of the urban environment; therefore it should be given serious attention. The aim of this work is to demonstrate the benefits of using GIS (Geographic Information System) to maintain the sewage system.

Key words: sewer system, maintenance, GIS, environmental protection 


\section{Uvod}

Ekspanzijom informacijskih mogućnosti i GIS se približio svakidašnjim potrebama čovjeka. Postoje različite definicije GIS-a, jedna od njih je: „GIS je veoma snažan skup informatičkih alata za sakupljanje, pohranjivanje, pretraživanje, pronalaženje, transformiranje i prikazivanje prostorno određenih podataka stvarnog svijeta, koji omogućavaju korištenje jedne ili više velikih baza podataka, izradbu modela i analitičke postupke za izvođenje korisniku potrebnih zaključaka." Bez obzira na razlike u definicijama, zajednička je činjenica da se GIS sustavi bave prostornim informacijama [1]. Razvojem upravljanja kanalizacijskim sustavom, GIS je postao neprocjenjiv alat zbog mogućnosti pružanja podataka kao što su: lokacija, promjeri cijevi, vrste materijala od kojih su cijevi rađene, datumi izgradnje i slično. Modelima GIS-a omogućuje se komunalnim poduzećima bolje praćenje i prilagodbe zakonima i propisima uz jednostavne, brze preglede i analize svih potencijalnih problematičnih područja te donošenje pravilnih odluka vezanih za razvoj i rekonstrukciju sustava odvodnje [2].

Glavna zadaća GIS-a odvodnje je upravljanje i evidencija objekata koji čine sustav odvodnje otpadnih voda, njihov oblik, položaj te svojstva koja posjeduju. Za razliku od komunalnih informacijskih sustava, GIS odvodnje otpadnih voda koncentrira se prvenstveno na prostornu komponentu sustava i objekte sustava. Zajedno sa svojstvima objekata sustava (atributima) i međusobnu topološku povezanost mrežnog tipa, čine sustav koji je sposoban zabilježiti oblik i stanje objekata, upravljati promjenama nad objektima, prikazivati objekte i sustav u cjelini te izvoditi analize i scenarije [3]. Osnovni objekti sustava uključuju: slivnike, revizijska okna, preljeve, crpne stanice, ispuste, tlačne vodove, otvorene i zatvorene kanale, uređaje za pročišćavanje otpadnih voda i sve druge objekte sustava. Svi ti objekti posjeduju svoju prostornu, uporabnu i sadržajnu komponentu, međusobno su povezani, a zajedno omogućuju sustavu ispunjenje svoje osnovne zadaće [4].

\section{Načini održavanja sustava}

Preduvjeti za dobro održavanje i pogon kanalizacijskog sustava, odnosno gospodarenje kanalizacijskim sustavom su dobro poznavanje sustava i njegovih karakteristika, potreban broj kvalitetnih kadrova, dobra organizacija i dovoljna financijska sredstva. Bez plana održavanja kanalizacijskog sustava, za čije je postojanje potrebno poznavanje karakteristika sustava (katastar vodova), ne može se provoditi organizirano i racionalno održavanje sustava, ne mogu se planirati potrebna materijalna i financijska sredstva, kao ni kadrovi. Budući da je kanalizacijski sustav specifičan za svako naselje, to zahtijeva i specifičan pristup kontroli i održavanju svakog sustava. Organizacija koja upravlja kanalizacijskim sustavom mora izraditi plan redovite kontrole i održavanja kanalizacijskog sustava. Održavanje i upravljanje kanalizacijskim sustavom danas, a pogotovo u budućnosti, bit će sve teže i složenije. Osnovni su razlozi sve veći zahtjevi vezani uz zaštitu čovjekova okoliša i sve složeniji uvjeti sakupljanja i odvođenja voda iz urbanih sredina, što shematski prikazuje slika 1 [5].

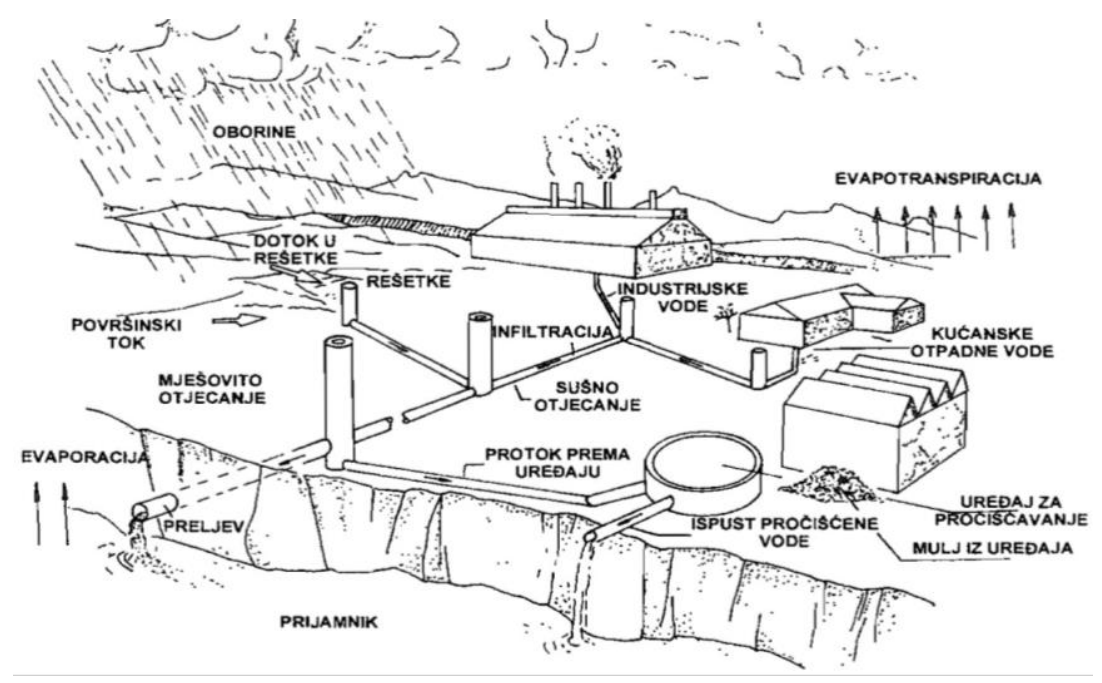

Slika 1 - Tipična shema gradskog kanalizacijskog sustava 
Razlikujemo redovito i incidentno održavanje. Redovito se održavanje uglavnom svodi na redovito snimanje stanja, povremeno čišćenje kanala, kišnih rešetki i objekata, a kod starijih mreža i na izmjenu dotrajalih dionica, te stalnu kontrolu stanja kanala i objekata. Potreba za čišćenjem se javlja zbog taloženja mulja i pijeska na pojedinim dionicama, prodiranja korijenja drveća u kanale, ili zbog toga što korisnici kanalizacije bacaju u nju krupne otpatke.

Incidentno održavanje odnosi se na intervencije vezane uz pucanje kanala, prevelika opterećenja, oscilacije razine podzemne vode ili nečeg drugog, zbog čega dolazi do istjecanja kanalske vode u zemljište ili obratno, podzemne vode u kanale. Sve to dovodi do oštećenja kanala, urušavanja ulica, oštećenja kolovoza i zagađenja okoliša, te prevelikog opterećenja kanalizacijskog sustava infiltriranim i drugim vodama. Potrebno je stalno pregledavati stanje kanalizacije, kako bi se na vrijeme uočili i otklonili nedostatci. Čišćenje kanala se obavlja mehaničkim sredstvima ili ispiranjem.

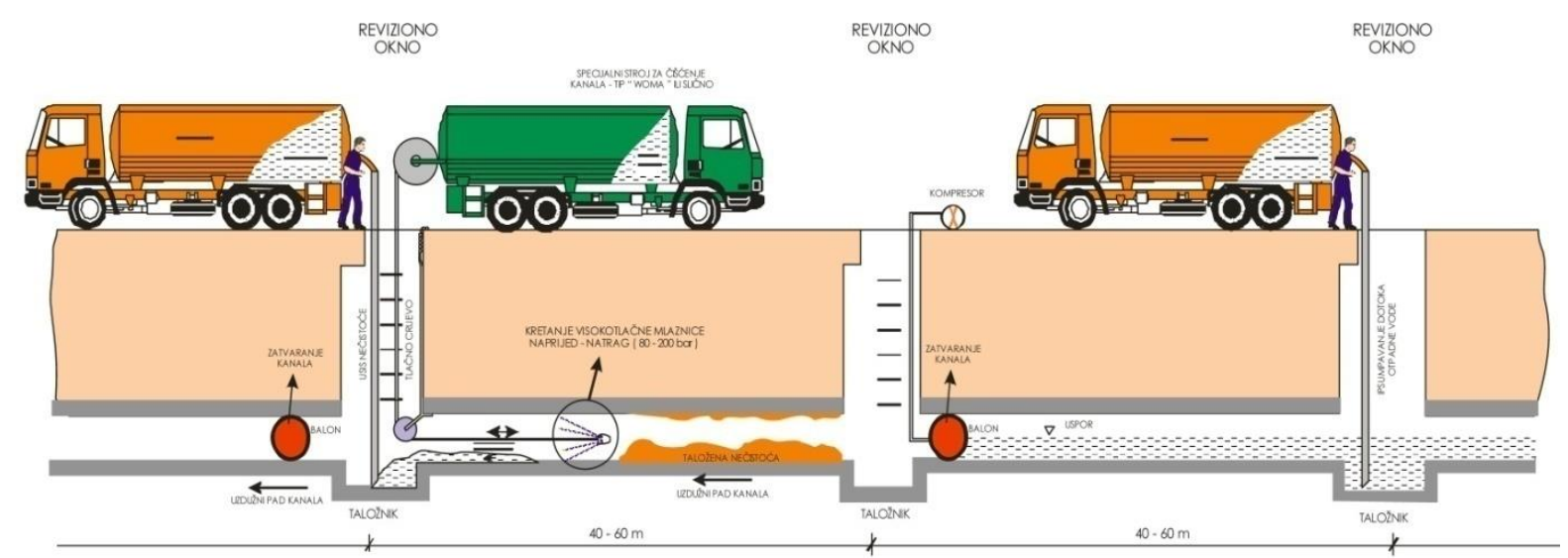

\section{Slika 2 - Shema čišćenja ulične kanalizacijske mreže [6]}

Čišćenje se obavlja četkama, lancima za razbijanje taloga, noževima za sječenje i čupanje korijenja, kukama, posudama za izvlačenje mulja, itd. Ovi predmeti se vuku kroz kanal ručno ili mehanički (slika 2, slika 3). Ispiranje se u većim gradovima danas uglavnom obavlja posebnim strojevima i uređajima koji mogu vrlo djelotvorno čistiti kolektore (slika 4). To su samohodne hidrauličke glave iz kojih štrca voda pod pritiskom i do 100 bara kapaciteta 300 do $600 \mathrm{l} / \mathrm{min}$. Ovi uređaji imaju dobar učinak na manjim profilima (do Ø 600mm) [3].

\subsection{Održavanje i pogon objekata kanalizacijskog sustava}

\subsubsection{Crpne stanice}

Održavanje crpnih stanica svodi se na redovito održavanje sve opreme, a prije svega održavanje crpki i automatike u skladu s uputama proizvođača. U redovito održavanje spada i povremena kontrola djelotvornosti crpki, naročito onih u oborinskoj i mješovitoj kanalizaciji. U tim uvjetima životni vijek rotora crpki je bitno kraći zbog abrazije pijeska, stoga je potrebna redovita izmjena rotora. Osim crpki, redovito treba kontrolirati i sve zaštitne uređaje, a naročito uređaje za ublažavanje tlačnog udara.

\subsubsection{Rasteretne građevine}

Kod rasteretnih građevina treba redovito kontrolirati stanje na preljevnom pragu i u prigušnici, kao i na svim uređajima, te obaviti odgovarajuća čišćenja i ispiranja. Uređaji - zaštitni, regulacijski i slično - kontroliraju se i održavaju sukladno s uputama proizvođača.

\subsubsection{Kišni bazeni}

Kišni se bazeni održavaju u skladu sa svojim karakteristikama. Kišni bazeni se redovito moraju kontrolirati najmanje prije i poslije kišnog razdoblja, a poželjno je poslije svakog punjenja. Kontrolom se nastoji utvrditi nastalo stanje u bazenu i potrebe za čišćenjem. Nakupljeni se talog redovito mora vaditi, a bazen ispirati. 


\subsubsection{Ispusti}

Ispusti se kontroliraju da bi se utvrdio njihov rad, ali i stanje u odnosu na stabilnost i hidraulička svojstva. Posebnu pozornost treba posvetiti difuzoru. To posebno vrijedi za duge podmorske ispuste čija je kontrola otežana i zahtijeva rad ronilaca ili korištenje posebne opreme. Kontrola ispusta mora se obaviti najmanje jedanput godišnje. Ispusti se moraju ispirati redovito dva i više puta godišnje, odnosno u skladu s potrebama. U kontrolu i održavanje ispusta spada i održavanje svih elemenata ispusta, a naročito zaštitnih uređaja i ozračnog okna.

\subsubsection{Ostali objekti (zaštitni uređaji i slično)}

Ostali objekti u kanalizacijskom sustavu također se moraju redovito održavati i pregledavati kako bi njihov rad bio trajan i u skladu s potrebama.

\section{Geografski informacijski sustavi (GIS)}

GIS je vrsta informacijskih sustava (informacijske tehnologije) za podršku unosu, obradu i analizu i prikaz prostornih informacija. Sadrži prostorne informacije organizirane kao skup prostornih podataka, neprostornih (opisnih podataka), tzv. atributa, te topoloških odrednica (odnos objekata prema okolini). Svi objekti smješteni u prostoru definirani su svojim koordinatama u nekom koordinatnom sustavu.

GIS (Geographic information system - Geografski informacijski sustav) je računalni alat koji služi pretraživanju baze podataka nekog sustava (npr. kanalizacije) te vizualizaciji rezultata pretraživanja ili upita, i to na različite načine i u različitim oblicima (bilo kao tematske karte, grafički ili tablični prikazi i dr.).

Općenito se može reći da je GIS postao standard u racionalnom pristupu rješavanja većine problema koji nas okružuju, tako da je danas i znatno zastupljen u suvremenom rješavanju problematike komunalne infrastrukture.

U konkretnom slučaju GIS-a kanalizacije Slavonskog Broda, primijenjen je hibridni model koji čine skenirani i geokodirani geodetski planovi i karte sustava odvodnje. Geodetski planovi starijeg datuma (dopunjeni analogni katastarski planovi mjerila 1:1000) i ostale geodetske podloge (dijelovi topografskih karata) su vektorizirani i geokodirani [7] te zajedno uklopljeni u Hrvatski državni koordinatni sustav (HDKS u ovom slučaju je GaussKrügerova konformna cilindrična poprečna modificirana projekcija). U ovom HDKS-u izrađuju se geodetski planovi i karte od njegovog uvođenja 1924. godine. Nadalje, geodetske podloge starijeg datuma su nadopunjene podatcima novije geodetske izmjere u vektorskom obliku. Selektiranjem nekog kanalizacijskog objekta mogu se dobiti podatci koji su upisani ili vezani uz taj objekt, dok ta tehnologija omogućuje još i različite analize i upite vezane uz prostorne podatke.

Prema tome, GIS omogućava preglednu, točnu i brzu analizu svih relevantnih podataka koji se povezuju uz kanalizacijski sustav, što predstavlja osnovnu podlogu za održavanje, kao i za utvrđivanje smjernica daljnjeg razvitka.

\subsection{GIS i zakonodavstvo}

GIS je zakonski potvrđen u Hrvatskoj 1994. uredbom Vlade RH, i to kroz nacionalni Program razvitka informacijske infrastrukture za gospodarenje prostorom i okolišem. Formirane su četiri grupe projekata: opći projekti, projekti uređenja prostora, projekti korištenja prostora i okoliša, projekti zaštite okoliša. Gotovo svi projekti danas rabe GIS tehnologiju pa je postignuta cjelovitost i konzistentnost definiranja sustava gospodarenja prostorom i okolišem u smislu strategije odgovarajuće informacijske infrastrukture.

Upotreba GIS-a je neophodna u sređivanju velike količine podataka, jer omogućuje preglednost i različita tematska povezivanja. Također, pomoću novih metoda prikupljanja i analiziranja podataka, GIS pospješuje statistiku te na taj način zamjenjuje tradicionalne statističke metode [8]. 


\section{Primjer primjene GIS-a za održavanje kanalizacijskog sustava Slavonskog Broda}

\subsection{Postojeće stanje kanalske mreže i objekata}

\subsubsection{Glavni kolektori, kanalska mreža i ispusti}

S obzirom na konfiguraciju terena, a također i zbog konstantnog širenja grada ka istoku i zapadu , glavni kolektori polagani su u smjeru sjever - jug, tako da maksimalno prihvaćaju otpadne vode kanalizacijskog područja. Na taj način je slivno područje kanalizacije grada Slavonskog Broda podijeljeno na tri samostalna podsustava (zapadni, centralni i istočni) sa svojim glavnim kolektorima i pripadnom gravitirajućom mrežom (slika 3).

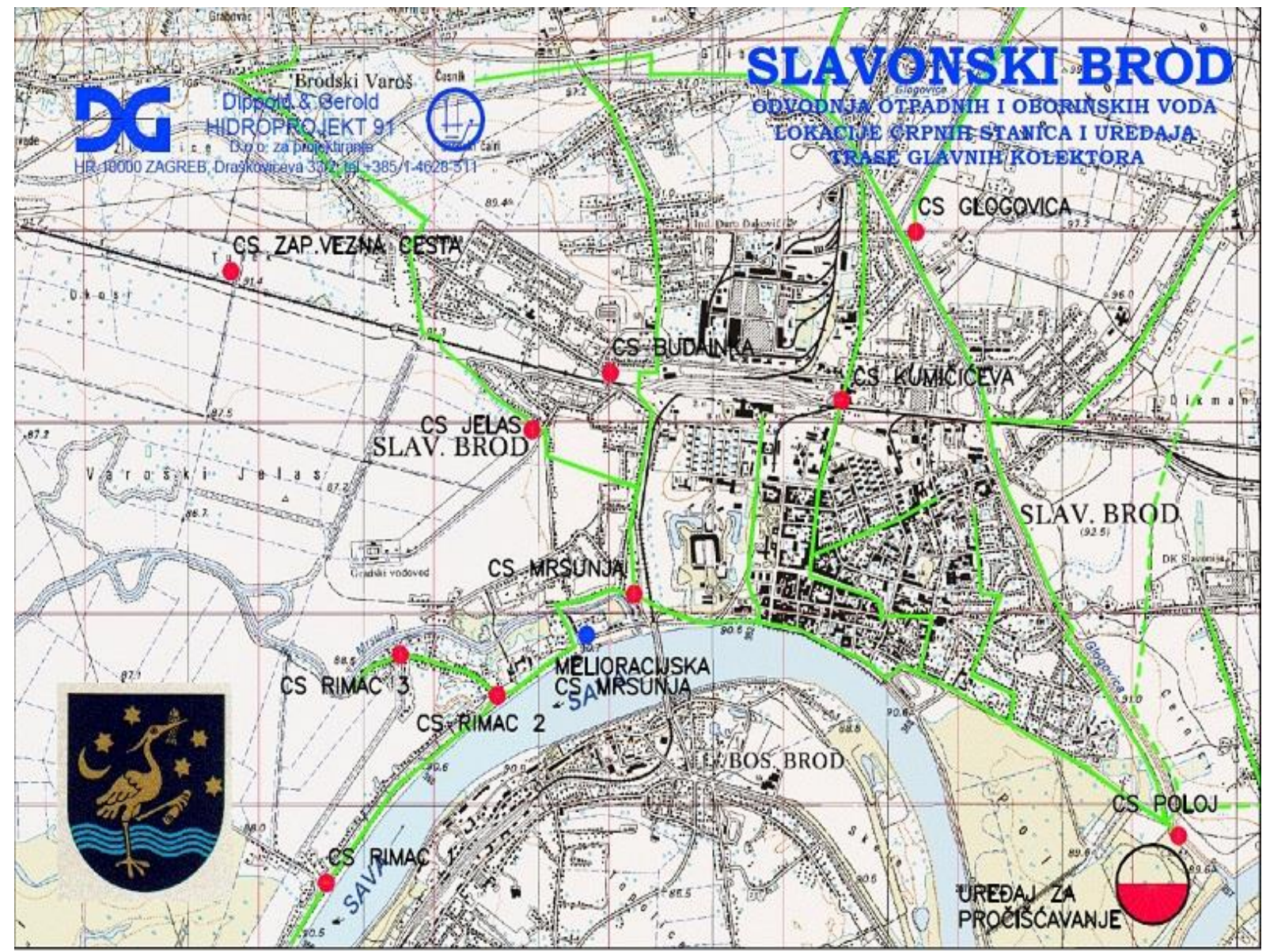

Slika 3 - Shematski prikaz mreže odvodnje

\subsection{Formiranje GIS-a kanalizacijskog sustava "Slavonski Brod"}

$\mathrm{Na}$ temelju obrade svih raspoloživih tehničkih podloga i podataka pribavljenih od nadležne komunalne tvrtke, formiran je GIS kanalizacijskog sustava "Slavonski Brod“. Ovdje se ističe da je situacijski i visinski položaj kanalizacijske mreže uglavnom utvrđen $\mathrm{s}$ visokim stupnjem točnosti, tj. uz korištenje raspoloživih geodetskih podloga. Dopuna ovakvog prikaza konfiguracije kanalizacijskog sustava izvršena je na temelju dodatno pribavljenih geodetskih podloga (u vektorskom formatu; tzv. "dwg" datoteke), kojima je uglavnom obuhvaćeno područje uz trase novoizgrađenih dionica kanalizacije. Ovakve obrade sastoje se od više pomoćnih radnji, kao npr.: izrada mrežne topologije, kontrola ispravnosti mrežne strukture, izrada radnih uzdužnih profila, "Flood Trace" analize, kontrola popunjenosti pridruženih tablica i dr. 
Nakon korekcija svih pogrešaka nastalih pri formiranju GIS-a kanalizacijskog sustava, neophodno je editiranje formirane mrežne topologije, te je provedeno njezino usmjeravanje (od uzvodnog prema nizvodnom revizijskom oknu), za što je izrađen posebni softver.

Da bi se dobili potrebni podatci za formiranje hidrauličkog modela, izvršena je dopuna baze podataka 0 visinama poklopaca i nivelete kanalizacije. Naime, na lokacijama gdje su nedostajali podatci o visini poklopca revizijskog okna, dopuna je provedena na temelju analize kartografskih podloga. Na mjestima s nepoznatim visinskim položajem nivelete kanala, dopuna je provedena uz analizu konfiguracije kanalizacijskog sustava šireg područja i interpolaciju s obzirom na poznate susjedne kote.

Svi objekti GIS-a kanalizacijskog sustava "Slavonski Brod" obrađeni su na način kojim se dobivaju cjelovite informacije o svim relevantnim podatcima vezanim uz ove objekte. Pritom je razina i način obrade (popis atributa, formati, odnosno, struktura baze podataka) usklađen sa zahtjevima daljnjeg svrsishodnog korištenja GIS-a kao osnovne tehničke podloge za održavanje i daljnji razvoj kanalizacijskog sustava.

Za sve izložene strukturne cjeline koje se uključuju u razmatrani kanalizacijski sustav, u GIS-u su deklarirani podatci o pojedinim objektima, te se na temelju određenih upita u formiranoj bazi podataka mogu izrađivati tematski kartografski i drugi prikazi (slika 4).

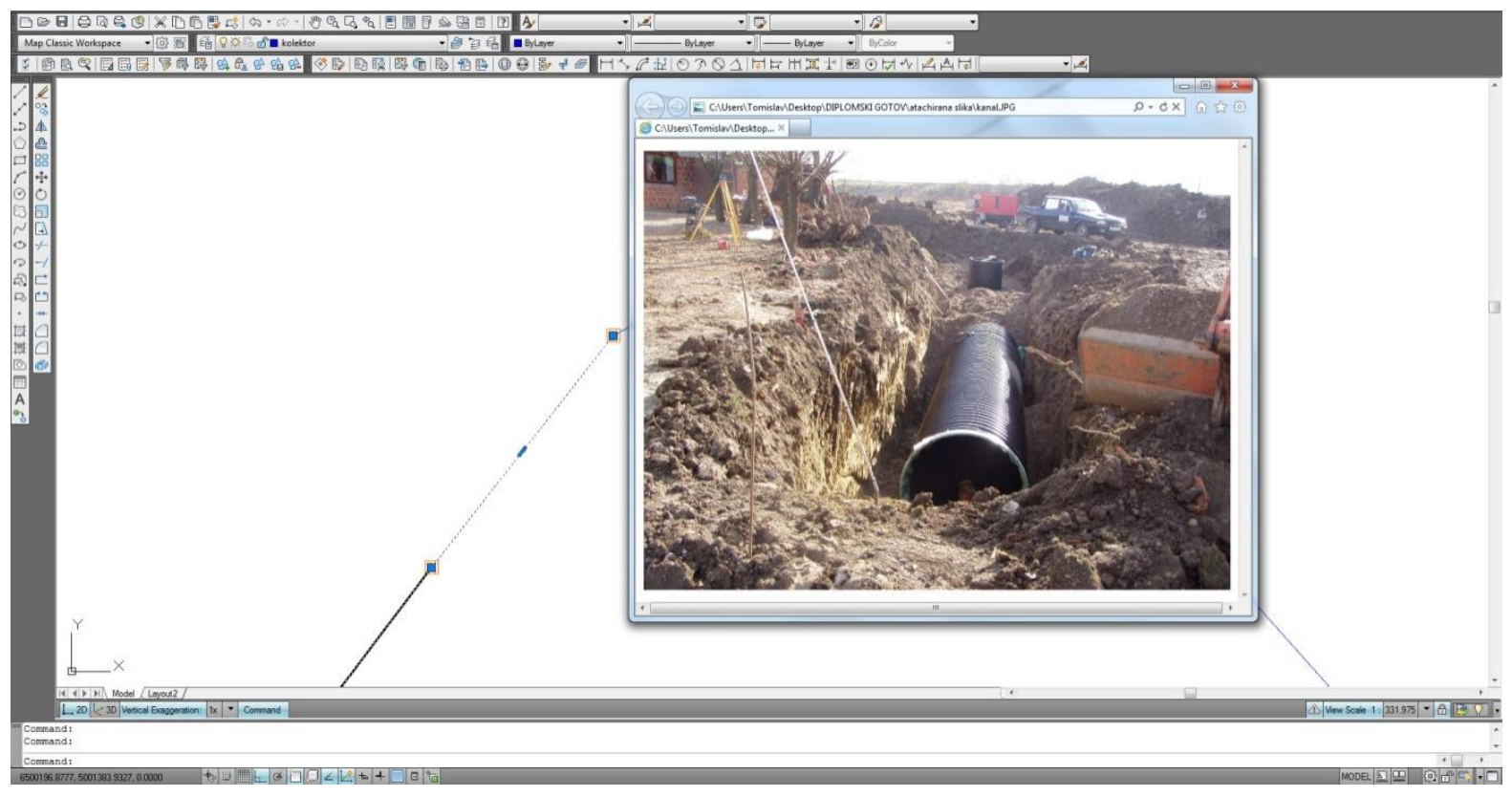

\section{Slika 4 - Kanal [9]}

Prema tome, pored grafičkih tematskih prikaza konfiguracije kanalizacijskog sustava, podatci o pojedinim objektima GIS-a mogu se predstaviti i u obliku tablica u kojima su sadržani svi temeljni tehnički podatci 0 postojećem stanju izgradnje razmatranog sustava odvodnje. sustavu:

Za potrebe kanalizacijskog sustava radimo mrežnu topologiju iz koje možemo prikazati različite podatke 0

- statistika sustava - daje nam podatke o broju revizijskih okana, broju kanala, te njihovoj ukupnoj, prosječnoj, minimalnoj i maksimalnoj duljini (slika 5)

- naredba Flood trace - provjerava otpore tečenju, od odabrane točke u svim smjerovima i pronalazi pogreške na kanalizacijskom sustavu

- $\quad$ naredba Shortest path - traži najkraći mogući put između dvije odabrane točke (okna)

- naredba Best route - odabire najbolji put tečenja između dva odabrana okna (slika 6). 


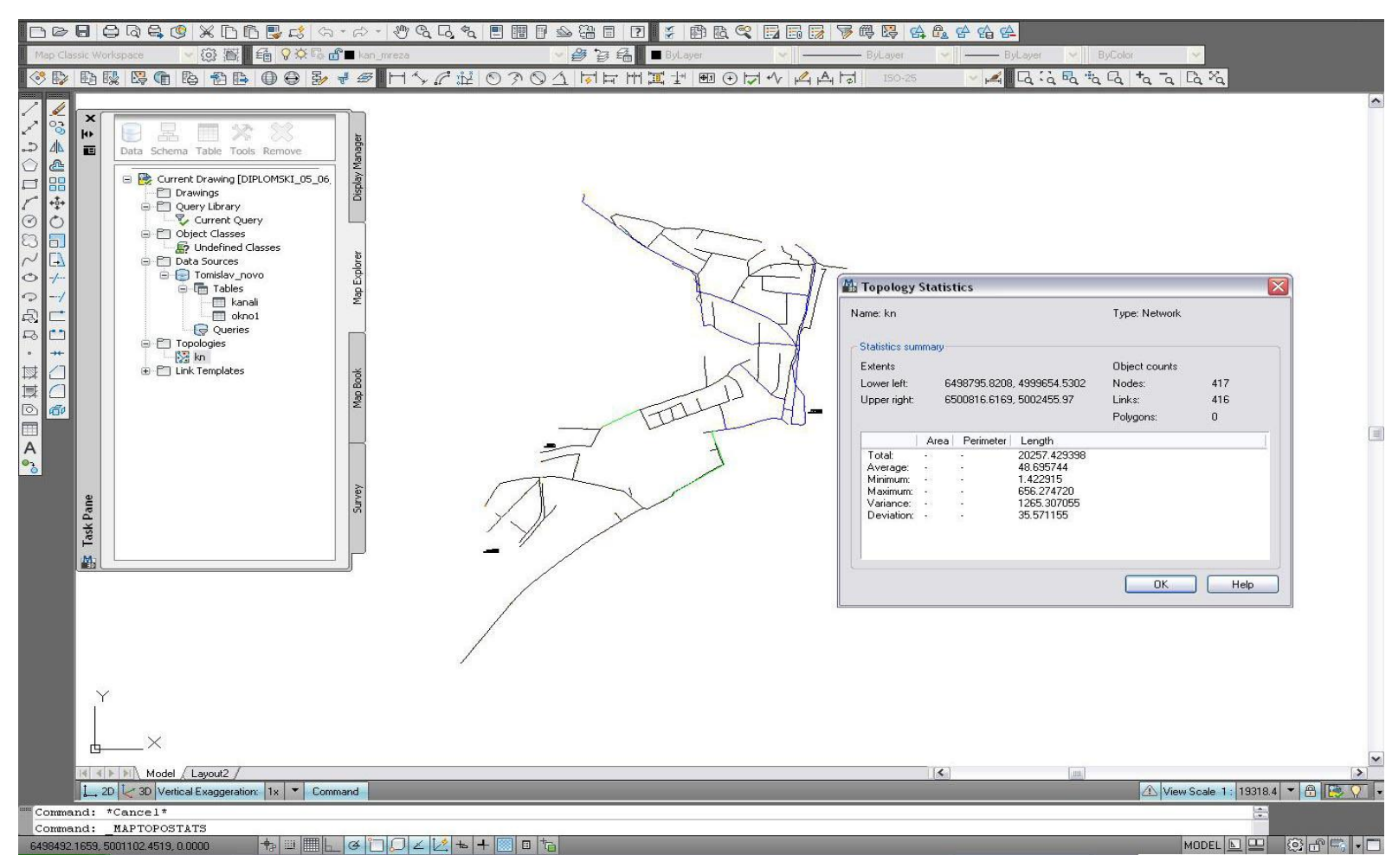

\section{Slika 5 - Statistika sustava [9]}

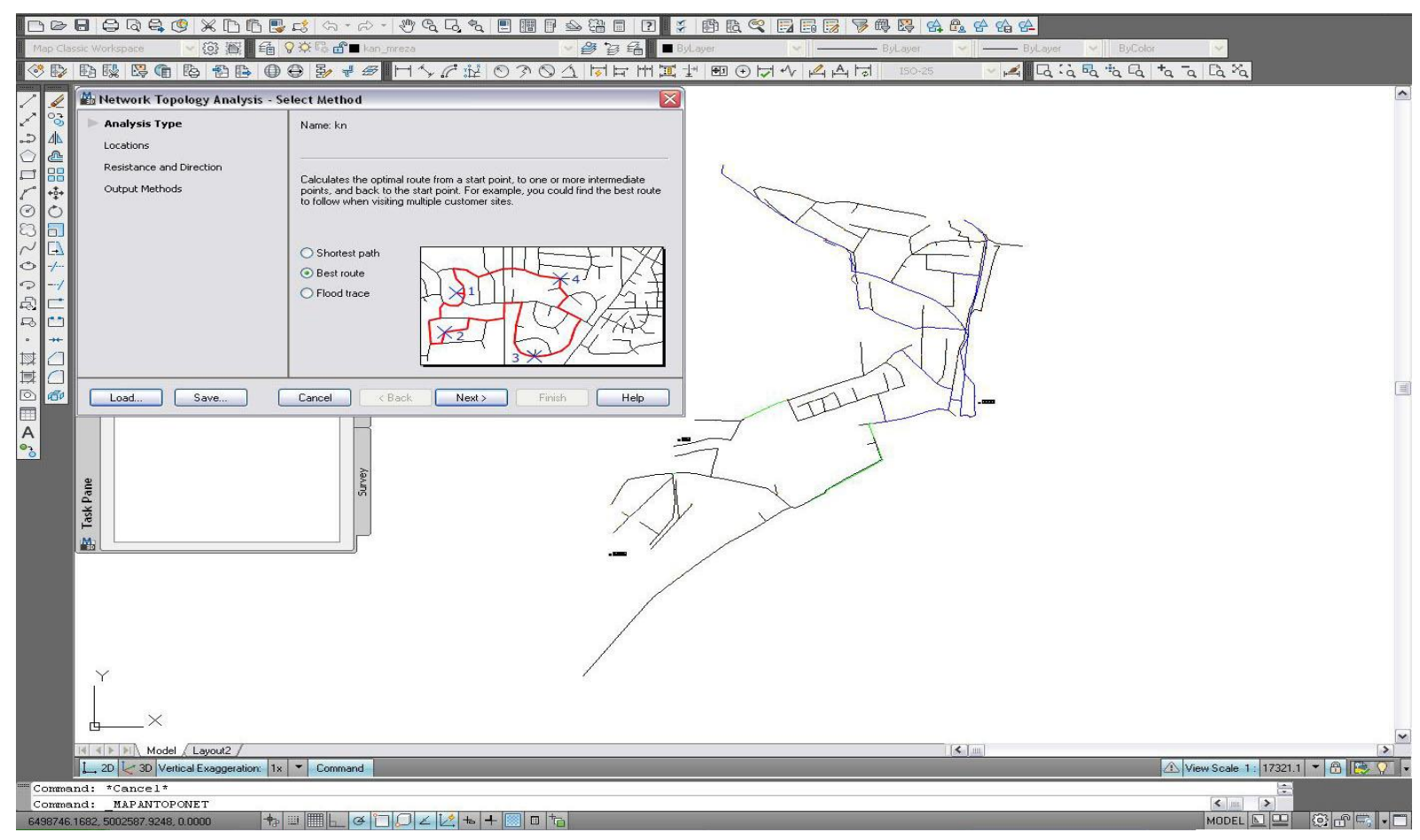

Slika 6 - Best route [9] 


\section{Prednosti GIS-a u održavanju kanalizacijskog sustava}

Vizualizacijom podataka u GIS-u omogućeno je da se velika količina atributnih podataka pohranjenih u računalu prikazuje u jednostavnom, slikovitom i čovjeku bliskom obliku. Unošenje u računalo prostornih podataka, te njihovo povezivanje s atributnim podatcima, omogućuje analizu, zaključivanje i logičko interpretiranje.

U rješavanju nekog problema GIS može povezati poglede praktički svih struka relevantnih za taj problem. GIS-om formiranim za simulaciju tečenja i upravljanja kanalizacijskim sustavom ostvaruje se dobra podloga za racionalno i održivo upravljanje sustavom [10].

Pregledom stvarnog stanja kanalizacijskog sustava na terenu te pohranjivanjem i detaljnim vođenjem svih informacija o objektima, omogućava se preciznija izrada plana održavanja kanalizacijskog sustava, kontrolna snimanja kamerom, kao i prijedlog mjera sanacije kritičnih mjesta.

\section{Zaključak}

Unutar mreže i objekata kanalizacije odvija se cijeli niz procesa, bioloških, fizikalnih i kemijskih. Ovi procesi svojom aktivnošću ugrožavaju funkcioniranje kanalizacije i imaju odgovarajuće štetne utjecaje na okoliš: smrad, plinovi, istjecanje, dotjecanje, korozija materijala i drugo.

Zbog svega ovoga, kanalizacija se mora redovito održavati kako bi njezino funkcioniranje bilo dobro i kako ne bi dovodila u opasnost radnike, okoliš, a time i zdravlje čovjeka. Ako se ne održava, kanalizacija može biti izvor mnogih zaraznih oboljenja i drugih štetnih djelovanja na čovjeka i okoliš. Postizanje održivosti i dugovječnosti kanalizacije zahtijeva redovito održavanje i čišćenje, dobru organizaciju rada, dostatne financije, dobre i obučene kadrove i druge elemente gospodarenja kanalizacijskim sustavom.

Razvojem urbanih područja, a paralelno s tim i kanalizacijskih sustava, tradicionalni pristup održavanja kanalizacije postao je nedostatan. Javila se potreba za digitalizacijom katastra vodova te izradom GIS-a koji bi omogućio efikasniji i ekonomičniji pristup rješavanju problema.

Izradom prostornog informacijskog sustava odvodnje kao prostornom evidencijom cjelokupnog sustava odvodnje s uspostavljenim hidrološko-hidrauličkim modelom funkcioniranja sustava, omogućeno je:

1 digitalna prostorna evidencija sustava javne odvodnje (s profilima i materijalima)

2 pregled funkcioniranja sustava javne odvodnje (sa stvarnim općim stanjem mreže)

3 analiza kapaciteta mreže

4 praćenje protočnosti mreže u realnom vremenu

5 brza provjera mogućnosti priključenja i dodatno opterećenje novih segmenata javne odvodnje i velikih industrijskih pogona

6 uspostava mreže mjerača protoke i uzorkivača

7 pojednostavljivanje i preciznije određivanje naknade za zaštitu voda

8 trenutačna reakcija u slučajevima iznenadnog zagađenja (čime se višestruko smanjuju troškovi sanacije i izbjegavaju nepotrebne štete)

9 nesmetano funkcioniranje sustava u slučajevima proglašavanja izvanrednog zagađenja, korištenjem hidrološko-hidrauličkog modela

10 korištenjem hidrološko-hidrauličkog modela, raspolaganje konkretnim podatcima o ponašanju sustava koji omogućavaju, uz minimalne troškove analize podataka, prilagođavanje sustava novonastaloj situaciji, čime se izbjegavaju znatni troškovi „novelacija“ i „optimalizacija“

11 kompatibilnost sa sustavom vodoopskrbe, te implementacija podataka o korištenim količinama vode na pojedinim segmentima sustava odvodnje

12 na temelju unesenih, prenesenih i očitanih podataka, kontrola vodonepropusnosti sustava, odnosno brza detekcija mogućih oštećenja na kolektorima

13 raspolaganje podatcima potrebnim za monitoring.

Vidljivo je kako nam GIS tehnologija znatno olakšava tip i strategiju održavanja za svaki pojedini dio sustava, uključujući postupke i učestalost. Očito je da se radi o vrlo složenom, zahtjevnom i obimnom zadatku koji zahtijeva cjelovit i odgovoran pristup. 


\section{Literatura}

[1] Grupa autora (1997): GIS u Hrvatskoj, INA - INDUSTRIJA NAFTE d.d. Sektor informatike, Zagreb

[2] Haines, D. (2006): GIS Improves Stormwater Management, Goverment Engineering, September-October, 2006.

[3] Kolarek, M. (2010): Primjena GIS-a u sustavima odvodnje otpadnih voda, Ekscentar, 12, 78-81

[4] Halapija, H.; Piskor, D.; Radeljić, I. (2008): Prostorni informacijski sustavi odvodnje - sinergija geodezije, građevine i informatike, Zbornik radova 1. simpozija ovlaštenih inženjera geodezije: Hrvatska geodezija izazovi struke u 21. stoljeću, HKAIG - Razred inženjera geodezije, Opatija 24.-26. listopad 2008.

[5] Margeta, J. (2009): Kanalizacija naselja: odvodnja i zbrinjavanje otpadnih i oborinskih voda, Građevinskoarhitektonski fakultet Sveučilišta u Splitu, Split, 2009.

[6] http://www.varkom.hr/documents/kanalizacija/SHEMA_CISCENJA_KANALIZACIJE.pdf (04.06.2012.)

[7] Jurišić, M.; Plaščak, I. (2009): Geoinformacijski sustavi GIS u poljoprivredi i zaštiti okoliša, Poljoprivredni fakultet Osijek, 2009.

[8] http://rgn.hr/ dperko/nids_dperkovic/predavanja/04_Znacajke_GIS-a_10062010.pdf (05.06.2012)

[9] Stvorić, T. (2012): Održavanje kanalizacijskog sustava uz primjenu GIS-a, Građevinski fakultet u Osijeku, diplomski rad

[10] http://www.geomodeling.hr/prostorni_informacijski_sustavi.html (7.6.2012.) 